\title{
Protection of Human Neutrophils by Endogenous Catalase
}

\author{
STUDIES WITH CELLS FROM CATALASE-DEFICIENT INDIVIDUALS
}

\author{
Dirk Roos, Ron S. WeEning, Sonja R. Wyss, and Hugo E. Aebi, Central Laboratory of \\ the Netherlands Red Cross Blood Transfusion Service, Laboratory for \\ Experimental and Clinical Immunology, and Pediatric Clinic, Binnengasthuis, \\ University of Amsterdam, Amsterdam, Netherlands; Medizinisch-chemisches \\ Institut der Universität Bern, Bern, Switzerland
}

\begin{abstract}
A B S TRACT To investigate the importance of catalase as a protecting enzyme against oxidative damage in phagocytic leukocytes, we have tested the functional capacity of neutrophils from two individuals homozygous for Swiss-type acatalasemia and from two individuals heterozygous for this deficiency. In the former cells, $25-30 \%$ of residual activity of catalase was present. In the latter cells, the values were close to normal.
\end{abstract}

Chemotaxis towards casein, release of lysosomal enzymes and hydrogen peroxide during phagocytosis of zymosan, and intracellular killing of Staphylococcus aureus were normal in all cells tested. Inhibition of heme enzymes with azide $(2 \mathrm{mM})$ enhanced the respiration and hexose monophosphate shunt activity of normal, but not of homozygous acatalasemic, neutrophils. This indicates that the enhancement in normal cells is, at least in part, due to catalase inhibition.

After 15 min preincubation with an $\mathrm{H}_{2} \mathrm{O}_{2}$-generating system (glucose plus glucose oxidase), the respiratory response to zymosan phagocytosis was strongly depressed in the homozygous acatalasemic and in normal, azide-treated neutrophils, but not in normal, untreated cells. Under these conditions, the release of lysosomal enzymes was depressed and that of lactate dehydrogenase enhanced, in catalase-deficient and in catalaseinhibited, but not in normal, neutrophils. During prolonged incubation with the $\mathrm{H}_{2} \mathrm{O}_{2}$-generating system $(30-60 \mathrm{~min})$, the reduction level of intracellular glutathione remained high and the hexose monophosphate shunt continued to operate normally in all cells tested. Thus, although the function of neutrophils without catalase activity was depressed by extracellular hydrogen peroxide, the $\mathrm{H}_{2} \mathrm{O}_{2}$ degradation via the glutathione redox system remained operative.

Received for publication 4 December 1.97 .9 and in revised form 19 February 1980).
The results indicate that the glutathione redox system by itself efficiently protects phagocytosing neutrophils against their own oxidative products. During heavy external oxidative stress, however, both catalase and the glutathione redox system are needed for adequate protection.

\section{INTRODUCTION}

Phagocytic leukocytes generate large amounts of hydrogen peroxide during phagocytosis and during activation by soluble products, e.g., chemotactic factors (1-3). In part, this $\mathrm{H}_{2} \mathrm{O}_{2}$ is released into the phagosomes where it exerts an antimicrobial action in combination with myeloperoxidase and chloride (4). Substantial amounts of hydrogen peroxide are also released into the extracellular medium (2). Thus, from the inside as well as from the outside, phagocytic leukocytes can be under heavy oxidative stress.

A number of recent observations indicates that phagocytic leukocytes, i.e., neutrophils, can be damaged by their own hydrogen peroxide. First, after preincubation of neutrophils with high concentrations of soluble activators, the subsequent reaction to chemotactic factors was diminished. In contrast, the chemotactic responsiveness of neutrophils from patients which chronic granulomatous disease, which fail to generate oxidative products, was undisturbed (5). Second, anaerobiosis or specific scavengers of hydrogen peroxide enhanced the rate of phagocytosis and the chemotactic responsiveness of normal neutrophils $(6,7)$. And third, neutrophils preincubated with a hydrogen-peroxide-generating system showed a diminished ingestion rate and a diminished response to chemotactic factors, unless protected by extracellular catalase (6).

Two systems are known that may potentially protect phagocytic leukocytes against oxidative damage by hydrogen peroxide. Catalase, primarily in the cell or- 
ganelles, decomposes hydrogen peroxide into water and oxygen. In the cytosol, the glutathione redox system reduces hydrogen peroxide by oxidizing NADPH, which is regenerated in the hexose monophosphate shunt. The protective function of the glutathione redox system in phagocytic leukocytes has been established with the aid of cells deficient in glutathione reductase (8) or glutathione synthetase (9). In this study, whether catalase has a similar function has been evaluated with neutrophils from acatalasemic individuals. The results indicate that catalase is not required for protection of resting or phagocytosing neutrophils, but it is indispensible for protection against external oxidative stress.

Case report. Two individuals homozygous for Swiss-type acatalasemia and two individuals heterozygous for this deficiency donated blood for this study. The two homozygotes had been recognized as such in previous studies by the low catalase activity in their erythrocytes $(<2 \%$ of the normal activity [10]) and in their leukocytes $(9-20 \%$ of the normal activity [11]), and by the decreased heat stability and increased electrophoretic mobility of the catalase residual activity in their erythrocytes (10) and leukocytes (11). The two heterozygotes had been recognized as such by family relation with the homozygotes and by the intermediate heat stability and electrophoretic mobility of the catalase in their blood cells $(10,11)$.

None of the acatalasemic individuals suffered from gangrenous oral infections or showed any predisposition to other infections. Informed consent of the donors was obtained before the start of this investigation.

\section{METHODS}

Zymosan (ICN Nutritional Biochemicals, Cleveland, Ohio) was opsonized by incubation in fresh human serum as previously described (12). Formaldehyde dehydrogenase (EC 1.2.1.1) was isolated from bovine liver as described by Koivusalo and Uotila (13). This preparation contained about $30 \mathrm{mg}$ protein $/ \mathrm{ml}$ with a specific activity of $3 \times 10^{-2} \mathrm{U} / \mathrm{mg}$. Other enzymes were obtained from Boehringer Mannheim Biochemica, Mannheim, West Germany.

Preparation of cells. Three times in the course of 2 years, blood from the acatalasemic individuals and from normal donors was drawn in heparin, transported, and stored at room temperature. Within $24 \mathrm{~h}$ after the donation, neutrophils were isolated by centrifugation of the blood over Ficoll-Isopaque $\left(d=1.077 \mathrm{~g} / \mathrm{cm}^{3}\right)$ and lysis of the erythrocytes in the pellet with isotonic ammonium chloride, as described (14). The cells were washed and suspended in phosphate-buffered $(10 \mathrm{mM})$ $\mathrm{NaCl}(138 \mathrm{mM}), \mathrm{pH} 7.4$, containing $0.6 \mathrm{mM} \mathrm{CaCl}, 1.0 \mathrm{mM}$ $\mathrm{MgCl}_{2}, 5.5 \mathrm{mM}$ glucose, and $0.5 \%$ (wt/vol) human albumin. The neutrophil suspensions were $\sim 95 \%$ pure, the yield was $\sim 80 \%$. The results obtained with the cells from the normal, 1-d-old blood were always in the range of the results obtained with cells from fresh normal blood.

Enzyme determinations. Catalase activity was measured with a Clark-type oxygen electrode (Yellow Springs Instrument Co., Yellow Springs, Ohio; model YSI 5331) as described by Del Rio et al. (15). In short, potassium phosphate buffer (50 mM, pH 7.4) was deoxygenated with nitrogen, hydrogen peroxide was added to a final concentration of $25 \mathrm{mM}$, and the oxygen production was measured. Thereafter, a lysate of 5,000 neutrophils with $0.2 \%$ (wt/vol) Triton $\mathrm{X}-100$ was added to the $0.5-\mathrm{ml}$ reaction vessel, and the rate of oxygen production was again recorded. The difference in the two rates of oxygen production was taken as a measure of the catalase activity in the lysate.

The activities of myeloperoxidase, superoxide dismutase, glutathione peroxidase, glutathione reductase, glucose-6phosphate dehydrogenase, and 6-phosphogluconate dehydrogenase were measured as described (8).

Functional tests. The assays for chemotaxis towards casein and intracellular killing of Staphylococcus aureus have been described (8). The extracellular release of lysozyme and $\beta$-glucuronidase from phagocytosing neutrophils was measured by incubating the cells $\left(5-10 \times 10^{6} / \mathrm{ml}\right)$ at $37^{\circ} \mathrm{C}$ with or without $1 \mathrm{mg}$ serum-opsonized zymosan $/ \mathrm{ml}$. Samples of $0.45 \mathrm{ml}$ were centrifuged in the cold and the supernates were stored at $4^{\circ} \mathrm{C}$. Enzyme determinations were performed in duplicate, as described by Goldstein et al. (12). The cytoplasmic enzyme, lactate dehydrogenase, was measured as an indicator of plasma membrane integrity. Enzyme release was expressed as a percentage of total enzymatic activity measured in simultaneously incubated cells to which Triton X-100 $(0.2 \%$, wt/vol $)$ had been added.

Metabolic reactions. Oxygen consumption was measured with an oxygen electrode as described (14).

Hydrogen peroxide production was measured in cell-free supernates by the oxidation of leukodiacetyl-2,7-dichlorofluorescein as described by Homan-Müller et al. (2). The cells were incubated in $2 \mathrm{mM} \mathrm{NaN}_{3}$ to prevent degradation of $\mathrm{H}_{2} \mathrm{O}_{2}$.

Production of ${ }^{14} \mathrm{CO}_{2}$ from $\left[1-{ }^{14} \mathrm{C}\right]$ glucose was determined as a measure of hexose monophosphate shunt activity, as described (8).

Reduced glutathione was measured with a mechanized version of the method described by Koivusalo and Uotila (13) in which reduced glutathione acts as a rate-limiting cofactor in the oxidation of formaldehyde by $\mathrm{NAD}^{+}$, catalyzed by formaldehyde dehydrogenase. Neutrophils $\left(20 \times 10^{6} / \mathrm{ml}\right)$ were incubated in a protein-free medium. Samples of $0.05 \mathrm{ml}$ were mixed with $1.5 \mathrm{ml}$ ice-cold $1 \mathrm{mM}$ EDTA and pumped into an Auto-Analyzer (Technicon Instruments Corp., Tarrytown, N. Y.) system. Composition and pump speed of the reagents are given (8). The increase in NADH was measured fluorometrically (excitation, $360 \mathrm{~nm}$; emission, $>400 \mathrm{~nm}$ ) after a 10 -min incubation at $37^{\circ} \mathrm{C}$. Samples of reduced glutathione in cell suspension medium were used as standards.

\section{RESULTS}

Enzymatic activities. The catalase activity in the purified blood cells of two homozygous and two heterozygous individuals with Swiss-type acatalasemia is shown in Table I. The homozygous-deficient erythrocytes had $\sim 1 \%$ of the normal catalase activity; the homozygous acatalasemic neutrophils contained 25-30\% of the normal activity. The heterozygous-deficient blood cells showed catalase activities in or close to the normal range.

Other enzymes involved in the oxidative metabolism were measured only in neutrophils. No abnormality was found either in homozygous or in heterozygous acatalasemic cells (Table II). Apparently, the activities of these enzymes were not raised to compensate for the reduced catalase activity. 
TABLE I

Catalase Activity in Blood Cells

\begin{tabular}{|c|c|c|c|c|}
\hline Subject & Erythrocytes & Neutrophils & Monocytes & Lymphocytes \\
\hline & $\begin{array}{c}\text { umol } \mathrm{H}_{2} \mathrm{O}_{2} \text { degraded } / \mathrm{min} / \mathrm{mg} \\
\text { hemoglobin }\end{array}$ & \multicolumn{3}{|c|}{ umol $\mathrm{H}_{2} \mathrm{O}_{2}$ degraded $/ \mathrm{min} / 10^{7}$ cells } \\
\hline Homozygote 1 & 3 & 93 & 65 & 14 \\
\hline Homozygote 2 & 5 & 102 & 48 & 15 \\
\hline Heterozygote 3 & 441 & 342 & 179 & 20 \\
\hline Heterozygote 4 & 276 & 114 & 180 & 38 \\
\hline $\begin{array}{l}10 \text { normal controls } \\
\text { (range) }\end{array}$ & $385-518$ & $208-49.3$ & $118-195$ & $21-49$ \\
\hline
\end{tabular}

The activities given for the acatalasemic cells are the means of the results obtained with cells isolated from two different blood donations, except for heterozygote 4, whose cells were tested only once. All values at $25^{\circ} \mathrm{C}$.

Functional tests. Chemotaxis of neutrophils was tested once, with the leading front method. The cells from the two homozygotes and from heterozygote 3 showed a normal spontaneous mobility $(17-18 \mu \mathrm{m}$; 25 controls, 15-22 $\mu \mathrm{m})$ and a low-normal chemotactic responsiveness toward casein $(57-62 \mu \mathrm{m} ; 25$ controls, 61-81 $\mu \mathrm{m})$. The cells from heterozygote 4 were not tested in this assay.

The release of lysosomal enzymes during phagocytosis is shown in Table III; no abnormality was found. Lactate dehydrogenase was not released to an appreciable extent, indicating that the cells remained intact during the 30 -min incubations. Resting cells released $<5 \%$ of any enzyme. After $15 \mathrm{~min}$ pretreatment at $37^{\circ} \mathrm{C}$ with the $\mathrm{H}_{2} \mathrm{O}_{2}$-generating system of glucose plus glucose oxidase $(0.05 \mathrm{U} / \mathrm{ml})$, the homozygous catalase-deficient neutrophils were severely depressed in the capacity to release lysosomal enzymes during phagocytosis. This was especially evident when the release of $\beta$-glucuronidase was measured. Moreover, the release of lactate dehydrogenase was strongly increased by the pretreatment. Similar effects were found with normal, azide- treated cells. No effect of pretreatment was found on the release of enzymes from resting cells.

The intracellular killing of $S$. aureus by the neutrophils of homozygote 1 was normal, the cells from heterozygote 3 killed the bacteria slower than normal (Table IV). Other acatalasemic cells were not tested in this respect.

A normal ultrastructure of homozygous and heterozygous acatalasemic neutrophils was observed on electron micrographs before, as well as after ingestion of zymosan particles (not shown).

Oxidative metabolism. Table $\mathrm{V}$ shows the oxygen consumption of resting neutrophils and the enhanced activity of this process in phagocytosing cells. The respiration of resting acatalasemic neutrophils was higher than that of normal cells. This was particularly evident in the homozygous catalase-deficient cells. The oxygen consumption during phagocytosis was normal in all cells tested. Addition of azide enhanced the respiration of phagocytosing normal neutrophils, but not of homozygous acatalasemic cells (Fig. 1). After 15 min preincubation with the $\mathrm{H}_{2} \mathrm{O}_{2}$-generating system,

TABLE II

Enzymatic Activities in Neutrophils

\begin{tabular}{|c|c|c|c|c|c|c|}
\hline Subject & MPO & SOD & GSH peroxidase & GSSG; reductase & G6PD & 6PGD \\
\hline & $\mu \mathrm{mol} / \mathrm{min} / 10^{*} \mathrm{cells}$ & $L^{\prime} / 10^{\pi}$ cells & \multicolumn{4}{|c|}{ nmol/min/10 $)^{\mp}$ cells } \\
\hline Homozygote 1 & 12 & 18 & 12 & 36 & 183 & 87 \\
\hline Homozygote 2 & 14 & 15 & 15 & 30 & 157 & 60 \\
\hline Heterozygote 3 & 19 & 26 & 10 & 39 & 197 & 45 \\
\hline $\begin{array}{l}10 \text { normal controls } \\
\text { (range) }\end{array}$ & $10-17$ & $11-26$ & $8-14$ & $17-37$ & $97-200$ & $35-107$ \\
\hline
\end{tabular}

Abbreviations used in this table: MPO, myeloperoxidase; SOD, superoxide dismutase; GSH, reduced glutathione; GSSG, oxidized glutathione dimer; G6PD, glucose-6-phosphate dehydrogenase; 6PGD, 6-phosphogluconate dehydrogenase.

All values at $25^{\circ} \mathrm{C}$. The enzymatic activities in the neutrophils of heterozygote 4 were not determined. 
TABLE III

Release of Lysosomal Enzymes from Phagocytosing Neutrophils

\begin{tabular}{|c|c|c|c|c|}
\hline \multirow[b]{2}{*}{ Subject } & \multirow[b]{2}{*}{$\begin{array}{l}\text { Preincubation* } \\
\text { with }\end{array}$} & \multicolumn{3}{|c|}{ Enzyme released $\downarrow$} \\
\hline & & Lysozyme & $\beta$-glucuronidase & $\begin{array}{c}\text { Lactate } \\
\text { dehydrogenase }\end{array}$ \\
\hline \multirow[t]{2}{*}{ Homozygote 1} & $\mathrm{NaCl}$ & 22.9 & 9.3 & 1.8 \\
\hline & $\mathrm{H}_{2} \mathrm{O}_{2}$ & $16.2(-29 \%)^{\prime \prime}$ & $1.9(-80 \%) \S$ & $6.3(+250 \%) \S$ \\
\hline \multirow[t]{2}{*}{ Homozygote 2} & $\mathrm{NaCl}$ & 17.9 & 6.0 & 1.8 \\
\hline & $\mathrm{H}_{2} \mathrm{O}_{2}$ & $11.1(-38 \%) \S$ & $2.3(-62 \%) \S$ & $7.5(+315 \%) \S$ \\
\hline \multirow[t]{2}{*}{ Heterozygote 3} & $\mathrm{NaCl}$ & 12.7 & 8.7 & 2.3 \\
\hline & $\mathrm{H}_{2} \mathrm{O}_{2}$ & $12.2(-4 \%)$ & $8.1(-7 \%)$ & $6.0(+160 \%)^{\prime \prime}$ \\
\hline \multirow{4}{*}{$\begin{array}{l}\text { Five normal controls } \\
\text { (mean) }\end{array}$} & $\mathrm{NaCl}$ & 17.9 & 7.7 & 2.5 \\
\hline & $\mathrm{H}_{2} \mathrm{O}_{2}$ & $15.7(-8 \%)$ & $6.5(-11 \%)$ & $3.3(+12 \%)$ \\
\hline & $\mathrm{NaN}_{3}$ & $17.6(-3 \%)$ & $7.5(-5 \%)$ & $2.3(-21 \%)$ \\
\hline & $\mathrm{H}_{2} \mathrm{O}_{2}+\mathrm{NaN}_{3}$ & $13.5(-31 \%)^{\prime \prime}$ & $4.2(-63 \%) \S$ & $6.2(+250 \%) \S$ \\
\hline
\end{tabular}

Total enzymatic activity in the cells (mean \pm SD of 20 normal neutrophil preparations): lysozyme, $56 \pm 17 \mu \mathrm{g} / 10^{7}$ neutrophils; $\beta$-glucuronidase, $2.3 \pm 1.0 \mathrm{nmol}$ phenolphthalein $/ 10^{7}$ neutrophils $\times$ min; lactate dehydrogenase, $425 \pm 138 \mathrm{nmol} \mathrm{NADH} / 10^{7}$ neutrophils $\times \mathrm{min}$. The total enzymatic activity found in the patients' cells was within the normal range.

The release of lysosomal enzymes from the acatalasemic cells was measured in duplicate in one experiment. The variance $(\mathrm{SD} / \mathrm{mean}, n=10$ ) of this assay is $5.2 \%$ (lysozyme), $3.0 \%$ ( $\beta$-glucuronidase), and $2.8 \%$ (lactate dehydrogenase). The release of lysosomal enzymes from the neutrophils of heterozygote 4 was not determined.

* Preincubation of $10^{7}$ neutrophils $/ \mathrm{ml}$ for $15 \mathrm{~min}$ at $37^{\circ} \mathrm{C}$ with either $0.05 \mathrm{U}$ glucose oxidase $/ \mathrm{ml}$ or with an equal volume of $154 \mathrm{mM} \mathrm{NaCl}$, with or without $2 \mathrm{mM}$ sodium azide, in the presence of $5.5 \mathrm{mM}$ glucose. After being washed, the cells were resuspended in incubation medium (Methods) and incubated at $37^{\circ} \mathrm{C}$ with $1 \mathrm{mg}$ serum-treated zymosan $/ \mathrm{ml}$.

Enzyme released during $30 \mathrm{~min}$ incubation, in percentage of total enzymatic activity in the cells. Parentheses, change in enzyme release caused by preincubation of cells.

$\S$ Significantly different $(P<0.005)$ from values obtained with similarly treated control cells.

"Significantly different $(P<0.01)$ from values obtained with similarly treated control cells.

TABLE IV

Intracellular Killing of S. Aureus by Neutrophils

\begin{tabular}{|c|c|c|c|}
\hline \multirow[b]{2}{*}{ Subject } & \multicolumn{3}{|c|}{ Percentage of living intracellular bacteria after } \\
\hline & $15 \min$ & $30 \mathrm{~min}$ & $60 \mathrm{~min}$ \\
\hline Homozygote 1 & 27 & 10 & 5 \\
\hline Heterozygote 3 & $34^{*}$ & $28 \ddagger$ & $19 \ddagger$ \\
\hline $\begin{array}{l}15 \text { normal controls } \\
\text { (range) }\end{array}$ & $6-38$ & $2-14$ & $1-6$ \\
\hline
\end{tabular}

The neutrophils were incubated for $7 \mathrm{~min}$ at $37^{\circ} \mathrm{C}$ with $S$. aureus (strain Oxford) in a ratio of 6 bacteria/acatalasemic cell and 2-10 bacteria/control cell. Thereafter, the remaining extracellular bacteria were killed and the neutrophils were incubated for another hour at $37^{\circ} \mathrm{C}$. The number of living intracellular bacteria was determined in triplicate at 15, 30, and $60 \mathrm{~min}$ after the initial $7 \mathrm{~min}$ (experimental details: 8). Results are expressed as mean percentage of living intracellular bacteria at $0 \mathrm{~min}$ after the initial $7 \mathrm{~min}$. This test was performed once with the acatalasemic cells. The variance (SD/ mean, $n=25$ ) of this assay is $12 \%$ (calculated from 100 duplicate samples).

* Significantly different from control values $(P<0.05)$.

$\$$ Significantly different from control values $(P<0.005)$. normal neutrophils consumed oxygen in response to zymosan particles with $\sim 75 \%$ of their original capacity. Homozygous catalase-deficient cells were damaged to a much larger extent by this pretreatment, whereas heterozygous acatalasemic cells behaved normally. Normal neutrophils preincubated with glucose plus glucose oxidase in the presence of azide were also strongly depressed in their subsequent reaction to zymosan. Boiling of the glucose oxidase, or addition of catalase to the preincubation of azide-treated, washed cells, prevented the oxidative damage (not shown).

The generation of hydrogen peroxide by the catalasedeficient neutrophils was in the normal range. In two separate experiments, we found that, at rest, these cells released a mean of $6-10 \mathrm{nmol} \mathrm{H}_{2} \mathrm{O}_{2} / 10^{6}$ neutrophils in $30 \mathrm{~min}$ (normal range, $0-11 ; n=19$ ). During phagocytosis of zymosan particles, the acatalasemic cells released a mean of $90-135 \mathrm{nmol} \mathrm{H}_{2} \mathrm{O}_{2} / 10^{6}$ neutrophils in $30 \mathrm{~min}$ (normal range, $79-187 ; n=20$ ). Without addition of azide, we were unable to measure any $\mathrm{H}_{2} \mathrm{O}_{2}$ in the cell-free supernates of either normal or catalasedeficient neutrophils. 


\begin{tabular}{|c|c|c|c|}
\hline \multirow[b]{2}{*}{ Subject } & \multirow{2}{*}{$\begin{array}{l}\text { Preincubation* } \\
\text { with }\end{array}$} & \multicolumn{2}{|c|}{ Addition to cells } \\
\hline & & None & Serum-treated zymosan \\
\hline & & nmol & consumed $/ 10^{6}$ cells/min \\
\hline \multirow[t]{2}{*}{ Homozygote 1} & $\mathrm{NaCl}$ & $0.49 \ddagger$ & 6.8 \\
\hline & $\mathrm{H}_{2} \mathrm{O}_{2}$ & 0.41 & $1.4(-75 \%) \downarrow$ \\
\hline \multirow[t]{2}{*}{ Homozygote 2} & $\mathrm{NaCl}$ & $0.43 \S$ & 8.4 \\
\hline & $\mathrm{H}_{2} \mathrm{O}_{2}$ & 0.38 & $0.4(-96 \%) \downarrow$ \\
\hline \multirow[t]{2}{*}{ Heterozygote 3} & $\mathrm{NaCl}$ & 0.30 & 6.6 \\
\hline & $\mathrm{H}_{2} \mathrm{O}_{2}$ & 0.52 & $6.3(-14 \%)$ \\
\hline \multirow[t]{2}{*}{ Heterozygote 4} & $\mathrm{NaCl}$ & 0.36 & 9.4 \\
\hline & $\mathrm{H}_{2} \mathrm{O}_{2}$ & NT & NT \\
\hline \multirow{2}{*}{$\begin{array}{l}9 \text { Normal controls } \\
\text { (range) }\end{array}$} & $\mathrm{NaCl}$ & $0.14-0.32$ & $6.4-9.2$ \\
\hline & $\mathrm{H}_{2} \mathrm{O}_{2}$ & $0.28-0.60$ & $5.2-7.4(-12$ to $-.35 \%)$ \\
\hline \multirow{2}{*}{$\begin{array}{l}4 \text { Normal controls } \\
\quad \text { (range) }\end{array}$} & $\mathrm{NaN}_{3}$ & $0.12-0.26$ & $5.5-7.8(+10$ to $-17 \%)$ \\
\hline & $\mathrm{H}_{2} \mathrm{O}_{2}+\mathrm{NaN}_{3}$ & $0.18-0.54$ & $2.8-4.0(-40$ to $-65 \%) \S$ \\
\hline
\end{tabular}

The results are the means of two to three separate experiments with acatalasemic cells. Parentheses, change in oxygen consumption caused by preincubation of the cells (means of paired experiments). The variance (SD/mean, $n=10$ ) of this assay is $4.7 \%$. NT, not tested.

* Preincubation of the neutrophils as indicated in the legend to Table III. After being washed, the cells were resuspended in incubation medium (Methods) and incubated at $37^{\circ} \mathrm{C}$ with or without $1 \mathrm{mg}$ serum-treated zymosan $/ \mathrm{ml}$.

$\$$ Significantly different $(P<0.005)$ from values obtained with similarly treated control cells.

$\$$ Significantly different $(P<0.01)$ from values obtained with similarly treated control cells.

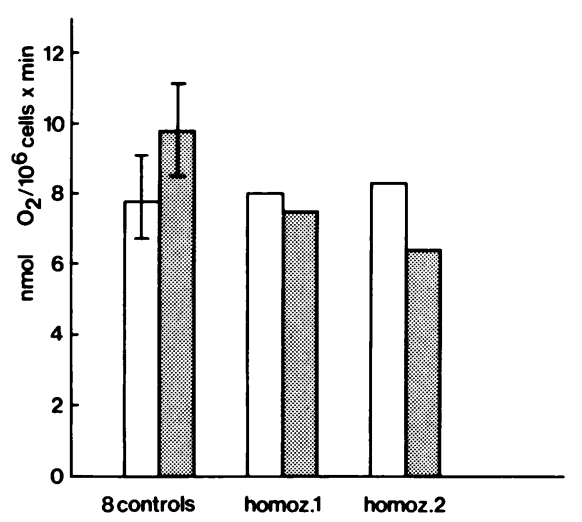

Figure 1 Effect of azide on the oxygen consumption of phagocytosing neutrophils. Normal and homozygous catalasedeficient neutrophils were incubated at about $3 \times 10^{6} / \mathrm{ml}$ with $1 \mathrm{mg}$ serum-treated zymosan $/ \mathrm{ml}$ at $37^{\circ} \mathrm{C}$ in an oxygraph. The mean rate of oxygen consumption with the acatalasemic cells, measured in two separate experiments, is given before and after addition of sodium azide $(2 \mathrm{mM}$ final concentration). Open bars, without azide; shaded bars, with azide. Normal values are given as mean $\pm \mathrm{SD}$ of eight experiments (mean stimulation by azide $\pm S D, 26 \pm 8 \%$; $t$ test for paired observations, $P<0.005)$. Homoz., homozygote.
The activity of the hexose monophosphate shunt, as measured by the generation of ${ }^{14} \mathrm{CO}_{2}$ from $\left[1-{ }^{14} \mathrm{C}\right]$ glucose was high in resting as well as in phagocytosing acatalasemic neutrophils (Table VI). Addition of sodium azide, which stimulates the shunt activity in normal cells, had no effect in the cells of homozygote 1 and heterozygote 3 was normal in this respect. When the catalase-deficient cells were incubated without particles in the presence of glucose plus glucose oxidase, the rate of ${ }^{14} \mathrm{CO}_{2}$ production was normal for up to $1 \mathrm{~h}$. Thus, although the preceding experiments had shown that catalase-deficient cells were damaged in their capacity to respond to phagocytosable particles, their ability to degrade $\mathrm{H}_{2} \mathrm{O}_{2}$ was still fully present.

The amount of reduced glutathione in phagocytosing neutrophils is shown in Fig. 2. In normal neutrophils and in those of homozygote 2 , there was a similar change in the level of reduced glutathione during phagocytosis. Sodium azide had no significant effect. The same was true for the neutrophils from the two heterozygotes (not shown). The cells from homozygote 1 were not tested. During incubation for $1 \mathrm{~h}$ with the $\mathrm{H}_{2} \mathrm{O}_{2}$-generating system, the levels of reduced glutathione were 
TABLE VI

Production of ${ }^{14} \mathrm{CO}_{2}$ from $\left[1-{ }^{14} \mathrm{C}\right]$ Glucose by Neutrophils

\begin{tabular}{|c|c|c|c|c|c|}
\hline \multirow[b]{2}{*}{ Subject } & \multicolumn{2}{|c|}{ At rest } & \multicolumn{2}{|c|}{ During phagocytosis } & \multirow{2}{*}{$\begin{array}{c}\text { With glucose } \\
+ \text { glucose } \\
\text { oxidase } \\
-\mathrm{NaN}_{3}\end{array}$} \\
\hline & $-\mathrm{NaN}_{3}$ & $+\mathrm{NaN}_{3}$ & $-\mathrm{NaN}_{3}$ & $+\mathrm{NaN}_{3}$ & \\
\hline & \multicolumn{5}{|c|}{ nmol glucose oxidized $/ 10^{6}$ neutrophils in $30 \mathrm{~min}$} \\
\hline Homozygote 1 & $1.9^{*}$ & $2.5^{*}$ & $14.2^{*}$ & 14.0 & NT \\
\hline Homozygote 2 & $1.0^{*}$ & $1.5^{*}$ & NT & 12.7 & 3.2 \\
\hline Heterozygote 3 & $1.7^{*}$ & $1.9^{*}$ & 9.8 & 12.6 & 4.5 \\
\hline Heterozygote 4 & $0.8^{*}$ & $1.8^{*}$ & NT & 10.6 & 3.0 \\
\hline $\begin{array}{l}\text { Normal controls } \\
\text { (range of } \\
\text { experiments) }\end{array}$ & $\begin{array}{c}0.1-0.5 \\
(5)\end{array}$ & $\begin{array}{c}0.2-0.7 \\
(11)\end{array}$ & $\begin{array}{c}8.3-10.5 \\
(5)\end{array}$ & $\begin{array}{c}9.4-14.3 \\
(11)\end{array}$ & $\begin{array}{c}2.0-5.4 \\
(4)\end{array}$ \\
\hline
\end{tabular}

Results as the mean of two separate experiments with acalasemic cells. The variance (SD/mean) of this assay is $5.4 \%$ (calculated from 100 duplicate samples). Sodium azide $(2 \mathrm{mM})$ did not change the reaction in resting normal cells $(P>0.1)$, but it did so significantly during phagocytosis $(P<0.01)$. Glucose oxidase was used at $0.05 \mathrm{U} / \mathrm{ml}$. NT, not tested.

* Significantly different from control values $(P<0.005)$.

hardly affected, in either normal cells with or without azide, or in catalase-deficient cells (not shown).

\section{DISCUSSION}

In this report, experiments are described with isolated neutrophils from individuals with Swiss-type acatalasemia. In the homozygous catalase-deficient neutrophils, a catalase residual activity of $25-30 \%$ of the mean normal activity was measured in fair agree-

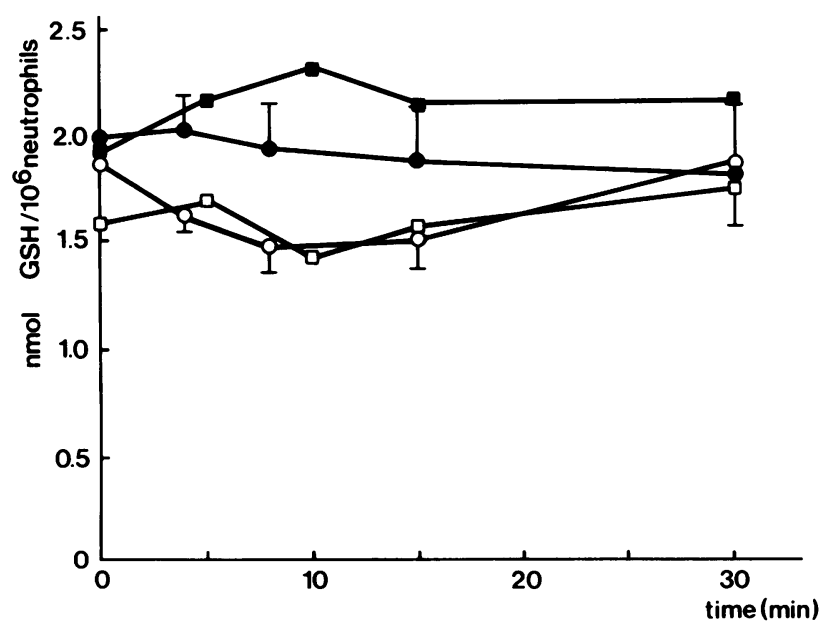

FIGURE 2 Effect of azide on levels of reduced glutathione in phagocytosing neutrophils. At time $=0 \mathrm{~min}$, serum-opsonized zymosan $\left(12-14 \times 10^{7}\right.$ particles $\left./ \mathrm{ml}\right)$ was added to the cells $\left(20 \times 10^{6} / \mathrm{ml}\right)$. Reduced glutathione $(\mathrm{GSH})$ was measured as described in Methods. Normal neutrophils with (O) and without (O) $2 \mathrm{mM} \mathrm{NaN}_{3}$, mean of five paired experiments; vertical bars indicate SD (differences not significant). Neutrophils from homozygote 2 with $(\square)$ and without ( $\square) 2 \mathrm{mM} \mathrm{NaN}$, results from one experiment. ment with published results obtained with a different catalase assay in total leukocytes $(9-20 \%$ of normal, $n=3$ ) (11). The much higher residual catalase activity in the homozygous-deficient leukocytes as compared with values found in the erythrocytes from the same individuals reflects the dependence of this activity on the turnover rate of the cells. In the heterozygous-deficient cells, catalase activities were close to normal $(10,11$; Table I), which may possibly be explained by the formation of hybrid molecules between normal and unstable catalase subunits (16).

Neutrophil respiration is slightly stimulated by azide and other heme inhibitors (14, 17; Fig. 1). Acatalasemic neutrophils did not show this azide-induced stimulation, which suggests that this effect is caused in normal cells by the azide inhibition of catalase. In this way, the reformation of oxygen from hydrogen peroxide in the catalase reaction is blocked, leading to an apparently faster rate of oxygen disappearance from the medium. This effect of azide cannot be attributed to inhibition of myeloperoxidase (17), because peroxidases react with hydrogen peroxide without production of oxygen.

Similarly, the lack of an azide-induced stimulation of the hexose monophosphate shunt in the acatalasemic neutrophils suggests that in normal neutrophils this stimulation is caused, in part, by the accumulation of hydrogen peroxide as a result of the catalase inhibition. The hexose monophosphate shunt is then activated via the glutathione redox cycle. The high hexose monophosphate shunt activity found in phagocytosing acatalasemic cells is in accord with this suggestion. Similar findings by Klebanoff et al. (17-19) in myeloperoxidasedeficient neutrophils led these investigators to conclude that the stimulatory effect of azide on the hexose monophosphate shunt activity in normal cells was, at least 
partly, due to inhibition of myeloperoxidase. However, myeloperoxidase-deficient neutrophils generate two to three times more $\mathrm{H}_{2} \mathrm{O}_{2}$ than normal neutrophils $(18,19)$. Therefore, the hexose monophosphate shunt activity in these cells may already have been stimulated to its maximum and for that reason, azide may have been without effect.

With our discontinuous assay, the release of hydrogen peroxide by phagocytosing neutrophils can only be measured in the presence of azide. Previously, we found that an azide-sensitive, $\mathrm{H}_{2} \mathrm{O}_{2}$-degrading substance is released into the medium together with the hydrogen peroxide itself (2). We have now observed that the same holds true for acatalasemic neutrophils. Because catalase is not an active enzyme in these cells, this observation suggests that myeloperoxidase is the main cause of hydrogen peroxide degradation in the medium of phagocytosing neutrophils.

Acatalasemic neutrophils showed a normal chemotactic response toward casein, a normal release of lysosomal enzymes during phagocytosis of zymosan, and a normal intracellular killing of S. aureus. Moreover, the respiratory response during zymosan ingestion was also normal, as was the level of reduced glutathione during this process. Apparently, the glutathione redox cycle alone is perfectly capable of protecting neutrophils against their own oxidative products. A similar conclusion can be drawn from the normal functional behavior of azide-treated normal neutrophils. This idea is also supported by the lack of recurrent infections in the acatalasemic individuals.

In striking contrast with the normal metabolic behavior of acatalasemic neutrophils, we (8) and others (9) have found that phagocytosing neutrophils with a genetic defect in the glutathione redox system are easily damaged by their own oxidative products. Thus, it follows that the glutathione redox system is more important for cell protection during phagocytosis than is catalase. Perhaps the ability of the glutathione reactions to repair (20), as well as prevent certain oxidative damage adds to its importance.

Glucose plus glucose oxidase is a convenient tool to study the effect of external oxidative stress on isolated cells (21). When neutrophils were subjected to a heavy oxidative stress from outside, both catalase and the glutathione redox system were needed for protection. This is concluded from the damage inflicted by glucose plus glucose oxidase on acatalasemic and on normal, azide-treated neutrophils, as well as on neutrophils with a deficiency of glutathione reductase (8). Only normal, untreated neutrophils, which are protected by catalase and by the glutathione redox system, can survive this external oxidative stress.

The nature of the oxidative damage is unknown, since the internal glutathione redox system was still intact in catalase-deficient and in catalase-inhibited neutro- phils after incubation with the $\mathrm{H}_{2} \mathrm{O}_{2}$-generating system. During this external oxidative stress, $\mathrm{H}_{2} \mathrm{O}_{2}$ was accumulating in the medium of normal, azide-treated neutrophils. Presumably, therefore, the glutathione system was working at its maximal capacity under these conditions, but was unable to remove all $\mathrm{H}_{2} \mathrm{O}_{2}$. In that situation, catalase proved to be essential for adequate cell protection. Apparently, a high level of reduced glutathione is no guarantee against oxidative damage. We have to consider the possibility that glutathione and catalase each protect certain localized cell structures, and that both systems are needed together for the preservation of the total cell function.

\section{ACKNOWLEDGMENTS}

We thank the blood donors for their kind cooperation and Miss Margriet van Schaik, Miss Annet Bot, Mr. Louis Meerhof, Mr. Alwin Voetman, Mr. Andy Wessels, and Mr. Rob van Zwieten for excellent technical assistance.

\section{REFERENCES}

1. Iyer, G. Y. N., D. M. F. Islam, and J. H. Quastel. 1961. Biochemical aspects of phagocytosis. Nature (Lond.). 192: $535-541$.

2. Homan-Müller, J. W. T., R. S. Weening, and D. Roos. 1975. Production of hydrogen peroxide by phagocytizing human granulocytes. J. Lab. Clin. Med. 85: 198-207.

3. Root, R. K., J. Metcalf, N. Oshino, and B. Chance. 1975. $\mathrm{H}_{2} \mathrm{O}_{2}$ release from human granulocytes during phagocytosis. I. Documentation, quantification, and some regulating factors. J. Clin. Invest. 55: 945-955.

4. Klebanoff, S. J. 1968. Myeloperoxidase-halide-hydrogen peroxide anti-bacterial system.J. Bacteriol. 95: 2131-2133.

5. Nelson, R. D., R. T. McCormack, V. D. Fiegel, M. Herron, R. L. Simmons, and P. G. Quie. 1979. Chemotactic deactivation of human neutrophils: possible relationship to stimulation of oxidative metabolism. Infect. Immun. 23: $282-286$.

6. Baehner, R. L., L. A. Boxer, J. M. Allen, and J. Davis. 1977. Autooxidation as a basis for altered function by polymorphonuclear leukocytes. Blood. 50: 327-335.

7. Boxer, L. A., J. M. Allen, and R. L. Baehner. 1978. Potentiation of polymorphonuclear leukocyte motile functions by 2,3-dihydrobenzoic acid. J. Lab. Clin. Med. 92: $730-736$.

8. Roos, D., R. S. Weening, A. A. Voetman, M. L. J. van Schaik, A. A. M. Bot, L. J. Meerhof, and J. A. Loos. 1979. Protection of phagocytic leukocytes by endogenous glutathione: studies in a family with glutathione reductase deficiency. Blood. 53: 851-866.

9. Spielberg, S. P., L. A. Boxer, J. M. Oliver, J. M. Allen, and J. D. Schulman. 1979. Oxidative damage to neutrophils in glutathione synthetase deficiency. Br.J. Haematol. 42: 215-223.

10. Aebi, H., S. R. Wyss, B. Scherz, and J. Gross. 1976. Properties of erythrocyte catalase from homozygotes and heterozygotes for Swiss-type acatalasemia. Biochem. Genet. 14: 791-807.

11. Wyss, S. R., and H. Aebi. 1975. Properties of leukocyte catalase in Swiss-type acatalasemia: a comparative study of normals, heterozygotes and homozygotes. Enzyme (Basel). 20: 257-268.

12. Goldstein, I. M., D. Roos, H. B. Kaplan, and G. Weiss- 
mann. 1975. Complement and immunoglobulins stimulate superoxide production by human leukocytes independently of phagocytosis.J. Clin. Invest. 56: 1155-1163.

13. Koivusalo, M., and L. Uotila. 1974. Enzymic method for the quantitative determination of reduced glutathione. Anal. Biochem. 59: 34-45.

14. Weening, R. S., D. Roos, and J. A. Loos. 1974. Oxygen consumption of phagocytizing cells in human leukocyte and granulocyte preparations. A comparative study.J. Lab. Clin. Med. 83: 570-576.

15. Del Rio, L. A., M. G. Ortega, A. L. Lopez, and J. L Gorgé. 1977. A more sensitive modification of the catalase assay with the Clark oxygen electrode. Application to the kinetic study of the pea leaf enzyme. Anal. Biochem. 80: 409-415.

16. Scherz, B., E. J. Kuchinskas, S. R. Wyss, and H. Aebi. 1976. Heterogeneity of erythrocyte catalase. Dissociation, recombination and hybridization of human erythrocyte catalases. Eur. J. Biochem. 69: 603-613.

17. Klebanoff, S. J., and C. B. Hamon. 1972. Role of myelo- peroxidase-mediated antimicrobial systems in intact leukocytes. J. Reticuloendothel. Soc. 12: 170-196.

18. Klebanoff, S. J., and S. H. Pincus. 1971. Hydrogen peroxide utilization in myeloperoxidase-deficient leukocytes: a possible microbicidal control mechanism.J. Clin. Invest. 50: $2226-2229$.

19. Rosen, H., and S. J. Klebanoff. 1976. Chemiluminescence and superoxide production by myeloperoxidase-deficient leukocytes. J. Clin. Invest. 58: 50-60.

20. Flohé, L., and W. A. Günzler. 1976. Glutathione-dependent enzymatic oxidoreduction reactions. In Glutathione, Metabolism and Function. I. M. Arias and W. B. Jacoby, editors. Raven Press, New York. pp 17-34.

21. Aebi, H., and H. Suter. 1974. Protective function of reduced glutathione (G-SH) against the effect of peroxidative substances and of irradiation of the red cell. In Glutathione. L. Flohé, H. Ch. Benöhr, H. Sies, H. D. Waller, and A. Wendel, editors. Georg Thieme Verlag, Stuttgart, West Germany. pp. 192-199. 